DOCUMENTA

\title{
HOMENAGEM A OTÁVIO VELHO
}

Os textos seguintes, de autoria de Clara Mafra e Roque de Barros Laraia, foram apresentados no encontro "Fronteiras da Antropologia: Seminário em Homenagem a Otávio Velho", que ocorreu no dia 7 de junho de 2006, organizado pelo Programa de Pós-Graduação em Antropologia Social/ Museu Nacional/UFRJ, por ocasião da outorga que lhe foi feita pela UFRJ do título de Professor Emérito. A mesa foi composta por Roque de Barros Laraia, Ricardo Benzaquen de Araújo, João Pacheco de Oliveira Filho e Clara Mafra. Infelizmente, não foi possível incluir aqui os textos dos demais membros da mesa, tal como se previra originalmente.

A Editoria 